Arq. Bras. Med. Vet. Zootec., v.66, n.2, p.433-438, 2014

\title{
Brainstem auditory evoked potential testing in Dalmatian dogs in Brazil
}

\author{
[Potencial evocado auditivo de tronco encefálico em cães da raça Dálmata no Brasil] \\ M.I.P. Palumbo ${ }^{1}$, L.A.L. Resende ${ }^{2}$, I.G.J. Mayhew ${ }^{3}$, A.S. Borges ${ }^{1 *}$ \\ ${ }^{1}$ Faculdade de Medicina Veterinária e Zootecnia - Universidade Estadual Paulista "Júlio de Mesquita Filho" \\ (FMVZ-Unesp) - Botucatu, SP \\ ${ }^{2}$ Faculdade de Medicina de Botucatu - Universidade Estadual Paulista "Júlio de Mesquita Filho" \\ (FMB-Unesp) - Botucatu, SP \\ ${ }^{3}$ Institute of Veterinary, Animal and Biomedical Sciences, College of Sciences, \\ Massey University, Palmerston North, New Zealand
}

\begin{abstract}
The brain stem auditory-evoked potential (BAEP) is an electrophysiologic test that detects and records the electrical activity in the auditory system from cochlea to midbrain, generated after an acoustic stimulus applied to the external ear. The aim of this study is to obtain normative data for BAEP in Dalmatian dogs in order to apply this to the evaluation of deafness and other neurologic disorders. BAEP were recorded from 30 Dalmatian dogs for a normative Brazilian study. Mean latencies for waves I, III, and V were $1.14( \pm 0.09), 2.62( \pm 0.10)$, and $3.46( \pm 0.14) \mathrm{ms}$, respectively. Mean inter-peak latencies for IIII, III-V, and I-V intervals were $1.48( \pm 0.17), 0.84( \pm 0.12)$, and $2.31( \pm 0.18) \mathrm{ms}$, respectively. Unilateral abnormalities were found in $16.7 \%$ of animals and bilateral deafness was seen in one dog. The normative data obtained in this paper is compatible with other published data. As far as we know this is the first report of deafness occurrence in Dalmatian dogs in Brazil.
\end{abstract}

Keywords: dog, deafness, auditory evoked potential

\section{RESUMO}

O potencial evocado auditivo de tronco encefálico (BAEP) é um teste eletrodiagnóstico que detecta e registra a atividade elétrica do sistema auditivo desde a cóclea até o tronco encefálico, gerada após a emissão de um estímulo acústico na orelha externa. O objetivo deste estudo é obter dados normativos para o BAEP em cães da raça Dálmata para usá-lo para detecção de surdez e de outras alterações neurológicas. BAEP foi obtido de 30 cães da raça Dálmata para um estudo normativo no Brasil. As latências médias para as ondas I, III e V foram 1,14ms ( $\pm 0,09)$; 2,62ms $( \pm 0,10)$ e 3,46ms $( \pm 0,14)$, respectivamente. A média das latências dos intervalos I-III, III-V e I-V foi 1,48ms ( $\pm 0,17)$; 0,84ms $( \pm 0,12)$ e 2,31ms $( \pm 0,18)$, respectivamente. Alteração unilateral foi observada em $16,7 \%$ dos animais, $e$ surdez bilateral foi observada em um cão. Os dados normativos obtidos neste trabalho são compatíveis com outros dados já publicados. Segundo a revisão realizada, este é o primeiro relato da ocorrência de surdez em cães da raça Dálmata no Brasil.

Palavras-chave: cão, surdez, potencial evocado auditivo

\section{INTRODUCTION}

Brainstem auditory evoked potential (BAEP) recording is a useful method for evaluating auditory and neurologic functions (Uzuka et al., 1996). The technique involves recording changes

Recebido em 18 de julho de 2012

Aceito em 5 de novembro de 2013

*Autor para correspondência (corresponding author)

E-mail: asborges@fmvz.unesp.br in electrical potentials from the surface of the scalp in response to a transient auditory stimulus, commonly in the form of a "click" (Kay et al., 1984). Numerous reports have been published using BAEPs in dogs (Marshall, 1985; Strain et al., 1992; Kawasaki and Inada, 1994). Since the test is well tolerated, quick, and provides 
objective results from animals, it is a rational test for screening breed dogs with a high incidence of deafness, such as Dalmatians (Marshall, 1986).

Over the past thirty years BAEP testing has been widely used for different purposes in veterinary practice and is commonly used to evaluate deafness, particularly to identify inherited and senile deafness (Strain et al., 1992; Luttgen, 1994; Strain, 1996), to determine a dog's auditory threshold (Kay et al., 1984; Marshall, 1986) and to evaluate drug toxicity (Uzuka et al., 1996). BAEPs provide a robust evaluation of brainstem integrity and can be used in head trauma and inflammatory disease cases, as well as other conditions when an animal is comatose and cranial nerve reflexes cannot be evaluated (Luttgen, 1994; Steiss et al., 1994).

In normal animals, BAEP recordings consist of five to seven reproducible waves which occur within 10ms after a click stimulus (Luttgen, 1994; Webb, 2009). Studies suggest that waves I to III are mostly generated by the cochlear branch of the VIII ${ }^{\text {th }}$ cranial nerve, the cochlear nucleus, and the olivary complex. Waves IV to VII are mostly generated by one or more of the following structures: the nucleus of the lateral lemniscus, the caudal colliculus, or the medial geniculate nucleus (Steiss et al., 1994).

Although normal values obtained from humans in different laboratories are relatively uniform, normative data are necessary for each animal species and each testing laboratory. The aim of this study is to obtain normative data for Dalmatian dogs in order to apply this to the evaluation of deafness and other neurologic disorders.

\section{MATERIALS AND METHODS}

Thirty Dalmatian dogs ranging between 1 and 8 years of age were recruited for this study. Owner consent was provided prior to evaluations. Approval was given for this experiment by the Ethics Committee on Animal Research for our Institution (process 117/2009). Each dog was clinically assessed, including neurological and otoscopic examinations. Owners were asked about any history of ototoxic agent use and their subjective assessment of hearing. Only one
Dalmatian had suspected deafness, as it did not answer to auditory cues. Animals having a history of exposure to ototoxic agents, and those with evidence of a neurological disorder, the presence of excess cerumen in the external auditory canal or any other abnormality were excluded.

BAEP testing was performed at the Electrodiagnosis Laboratory, UNESP, Botucatu. During examinations, the dogs were awake and kept in a standing position or in sternal recumbency using only calming physical restraint. Only 1 extremely restless animal with clinically suspected deafness was sedated with intramuscular acepromazine $(0.05 \mathrm{mg} / \mathrm{kg}$ BW) and morphine $(0.5 \mathrm{mg} / \mathrm{kg} \quad \mathrm{BW})$. The body temperature of the animals ranged from $38.2^{\circ} \mathrm{C}$ to $39.2^{\circ} \mathrm{C}$.

An active 29 gauge monopolar needle electrode (G1) was inserted subcutaneously at a point just below the most ventral and caudal aspect of the pinna, and a similar reference electrode (G2) was inserted at the vertex (Kay et al., 1984). The subcutaneous ground electrode was placed in the cervical dorsal neck (Marshall, 1986; Holliday and Te Selle, 1985). A filter band-pass was set at $200-3000 \mathrm{~Hz}$ sensitivity to $2.5 \mu \mathrm{V} / \mathrm{cm}$ and analysis time to $1 \mathrm{~ms} / \mathrm{cm}$. The headphones were positioned manually in the lower portion of the vertical portion of the external auditory meatus of each ear. Rarefaction clicks of $0.2 \mathrm{~ms}$ duration, $85 \mathrm{~dB}$ NHL intensity, at $13 \mathrm{~Hz}$ repetition were employed. Contralateral white-noise masking of 40dB NHL was used (Chiappa, 1997). A minimum of 2 successive recordings with 500 stimuli each were averaged. An automated common mode rejection ratio was used to eliminate or reduce artifacts.

All examinations were performed using a Synergy Viasys Healthcare ${ }^{\circledR}$ electrodiagnostic unit. Each test measured wave I, III and V absolute latencies, and I-III, III-V and I-V interpeak latencies for each side. Subsequently, waves were recorded on paper using a printer. Wave mean and standard deviation values were calculated and a comparison between left and right ears was tested with the Mann-Whitney test (Graphpad software). 


\section{RESULTS}

BAEP from a Dalmatian with normal hearing is shown in Figure 1. Of the 30 Dalmatians included in this study, unilateral absence of a response consistent with unilateral sensorineural deafness was seen in 5 (16.7\%) (Fig. 2). Of these 5 animals, 2 had left side and 3 right side deafness. An examination confirmed the clinical suspicion of bilateral deafness in 1 animal (Fig.3), which represents $3.3 \%$ of the study sample studied.

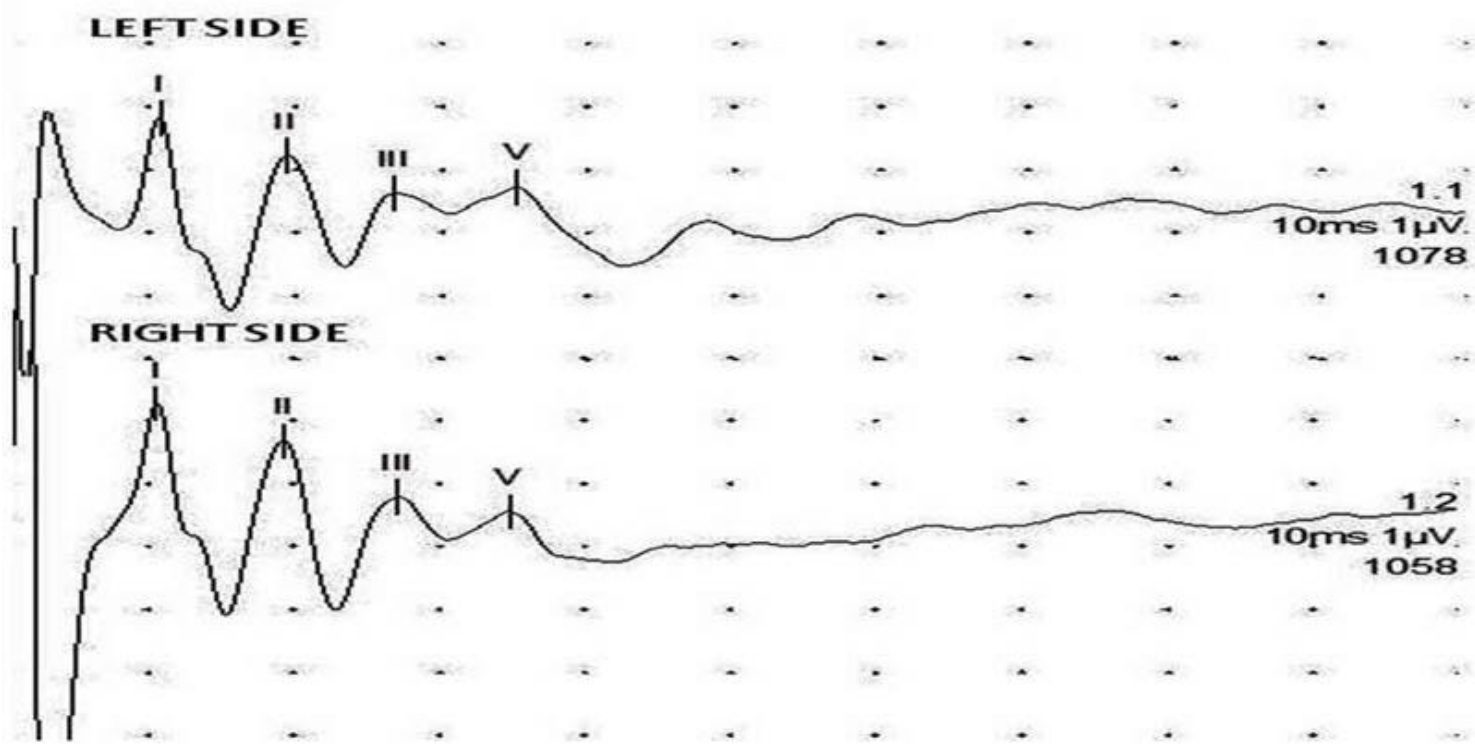

Figure 1. Dalmatian dog. Brainstem auditory evoked response tracing obtained from a normal adult animal. Each side was individually tested (Vertical division: $1 \mu \mathrm{V}$; horizontal division: 1 millisecond).

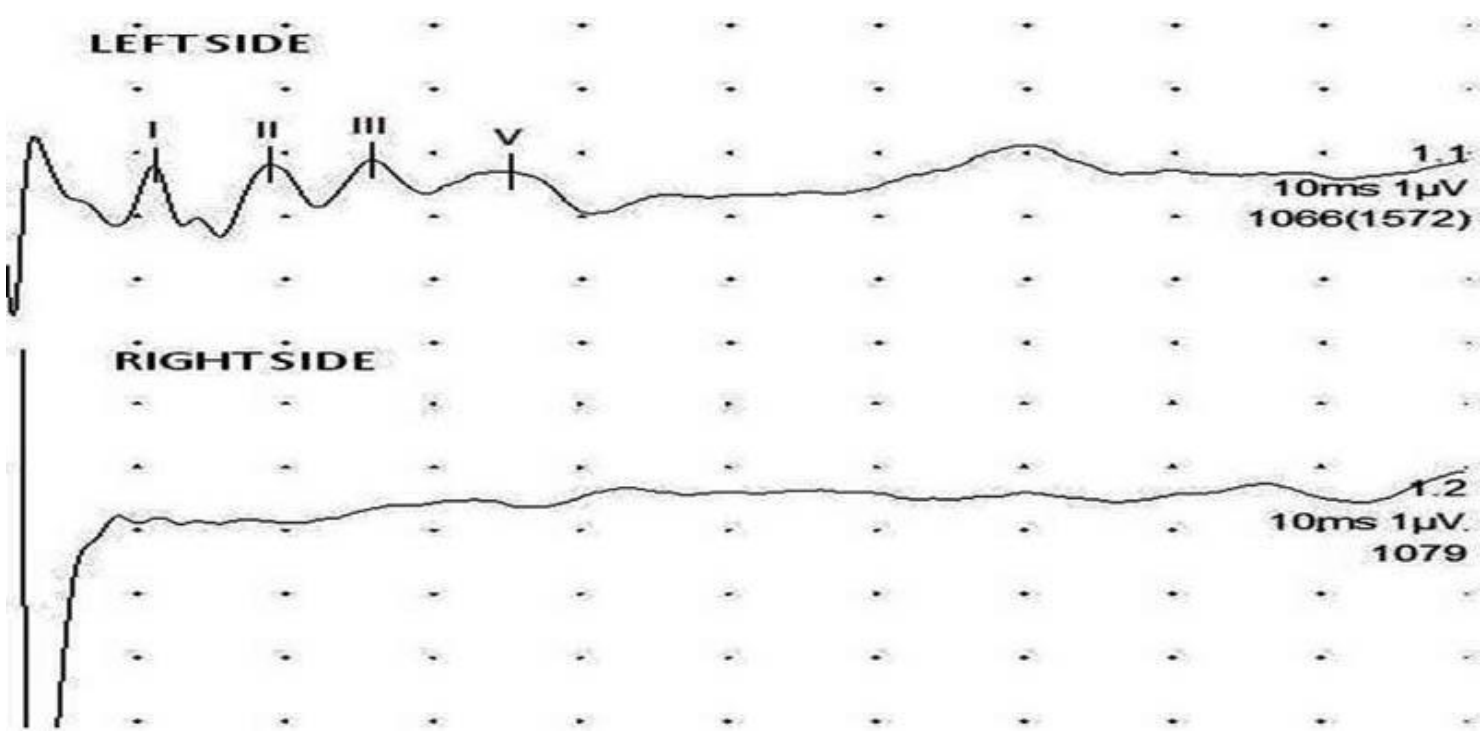

Figure 2. Dalmatian dog. Brainstem auditory evoked response tracing obtained from an adult dog with unilateral deafness. Each side was individually tested (Vertical division: $1 \mu \mathrm{V}$; horizontal division: 1 millisecond). 


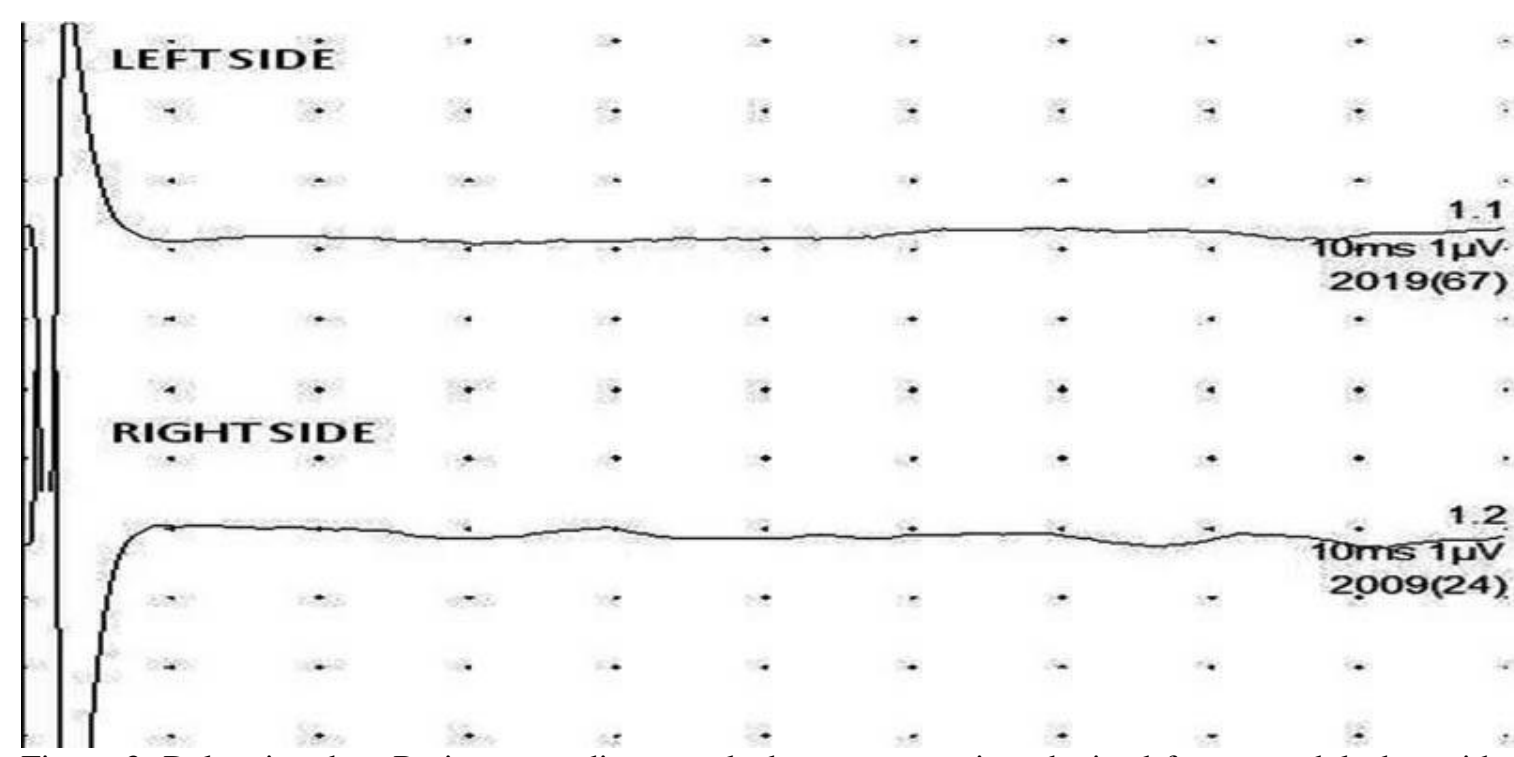

Figure 3. Dalmatian dog. Brainstem auditory evoked response tracing obtained from an adult dog with bilateral deafness. Each side was individually tested (Vertical division: $1 \mu \mathrm{V}$; horizontal division: 1 millisecond).

Both ears of all 30 dogs were evaluated. Leftversus-right data differences were not significant, so all results for both ears were combined, giving a total of 60 results, and 53 results were included in the normative study (48 from 24 normal dogs plus 5 unilateral normal data obtained from 5 dogs with unilateral deafness). Of the dogs with unilateral deafness, 2 had one blue and one brown eye and another 2 had brown eyes; the animal with bilateral deafness had 2 blue eyes. Table 1 shows mean, minimum and maximum, and standard deviation values for absolute latencies and inter-peak intervals (Table 1).

Table 1. Mean, minimum and maximum, and standard deviation values for I, III and V wave absolute latencies and I-III, III-V, and I-V inter-peak latencies in milliseconds (ms) from Dalmatian dogs ( $\mathrm{n}=53$ exams):

\begin{tabular}{cccc}
\hline Waves & Mean $(\mathrm{ms})$ & Minimum - Maximum $(\mathrm{ms})$ & Standard deviation $(\mathrm{ms})$ \\
\hline I & 1.14 & $1.02-1.36$ & 0.09 \\
III & 2.62 & $2.42-2.82$ & 0.10 \\
V & 3.46 & $3.10-3.78$ & 0.14 \\
I-III & 1.48 & $1.06-1.74$ & 0.17 \\
III-V & 0.84 & $0.62-1.16$ & 0.12 \\
I-V & 2.32 & $1.74-2.66$ & 0.18 \\
\hline
\end{tabular}

\section{DISCUSSION}

Many studies have reported that head size influences the amplitude and latency of BAEP waves (Allison et al., 1983; Trune et al., 1988; Pook and Steiss, 1990; Meij et al., 1992). Animals over one year old were selected to reduce the influence of head size in this normative study. Hearing loss associated with aging in dogs occurs around 8 to 10 years of age
(Haar et al., 2008), so such animals were excluded from our study. Increased wave latency in dogs with rectal temperatures below $36^{\circ} \mathrm{C}$ has been reported (Bodenhamer et al., 1985). To minimize interference from temperature, only animals with body temperatures between $38.2^{\circ} \mathrm{C}$ and $39.2^{\circ} \mathrm{C}$ were selected. Muscle activity can cause changes in electrical activity records from auditory pathways such that chemical restraint may be necessary in some dogs to minimize this 
interference (Wilson and Mills, 2005), which was the case for the animal with bilateral deafness who was extremely agitated and required sedation to allow examination.

This condition is widespread, occurring in approximately 80 dog breeds (Strain, 2004). About $20 \%$ of Dalmatian dogs have unilateral deafness, and $10 \%$ have bilateral deafness (Wood and Lakhani, 1998). Authors evaluated 1031 Dalmatians and found unilateral deafness in $21.6 \%$ and bilateral deafness in $8.1 \%$ (Strain et al., 1992). In our BAEP study of Dalmatians, we found unilateral deafness in $16.7 \%$ and bilateral in $3.3 \%$. These results are in agreement with the previous published latencies for dogs. No statistical differences between left and right sides were reported by others (Wood and Lakhani, 1998), similar to our data.

Sensorineural hearing loss is a congenital hereditary disease commonly seen in dogs with white pigmentation (Muhle et al., 2002). The suggestions for inheritance of deafness in Dalmatians include a dominant gene with incomplete penetrance, double dominant genes, or multifactorial recessive genes (Strain et al., 1992). Previous studies have identified statistically significant associations between deafness and a blue iris colour and white coat pigmentation (Strain, 2004; Platt et al., 2006). In the present article the occurrence was higher in dogs with one or two blue eyes.

While bilateral deafness may be obvious to the owner of an affected animal, unilateral deafness is exceedingly difficult to appreciate clinically because the animal can compensate for the disability (Strain, 1996; Strain, 1999; Muhle et al., 2002; Strain, 2004). Indeed, it is stated that animals with unilateral deafness cannot be distinguished from healthy animals by their owners using behavioral tests (Muhle et al., 2002). The hereditary deafness results from initial degeneration of the stria vascularis (Strain, 1996). In the Dalmatians, postnatal auditory function development proceeds normally through the first three weeks, then the stria vascularis rapidly degenerates, proceeding to deafness (Strain, 2011). It is therefore recommended that puppies of predisposed breeds undergo BAEP tests at 5 weeks old (Muhle et al., 2002).
The latency and interval values observed in this study are in agreement with those obtained in dogs by other authors (Marshall, 1985; Knowles et al., 1988; Haagen et al., 1989; Harcourt et al., 2010) but shorter than those reported in human studies (Anias et al., 2004; Bento et al., 2009).

\section{CONCLUSIONS}

To the best of our knowledge this is the first study to determine normative BAEP data and to document the occurrence of hearing loss in Dalmatian dogs in Brazil. Deafness was found in $20 \%$ (unilateral in $16.7 \%$, bilateral in $3.3 \%$ ) of dogs. The normal latency values obtained in this study can be used as a normal reference for comparing animals with various brain and cranial nerve disorders in our country.

\section{ACKNOWLEDGMENTS}

This study was supported by grants from Fundação de Amparo à Pesquisa do Estado de São Paulo - FAPESP (Process 2009/12290-8 and 2010/00518-1).

\section{REFERENCES}

ALLISON, T.; WOOD, C.C.; GOFF, W.R. Brain stem auditory, pattern-reversal visual, and short- latency somatosensory evoked potentials: latencies in relation to age, sex, ans brain and body size. Electroen. Clin. Neuro., v.55, p.619-636, 1983.

ANIAS, C.R.; LIMA, M.A.M.T.; KOS, A.O.A. Avaliação da influência da idade no potencial evocado auditivo de tronco encefálico. Rev. Bras. Otorrinolaringol., v.70, p.84-9, 2004.

BENTO, R.F.; SILVEIRA, J.A.M.; FERREIRA, M.R.M. et al. Estudo do padrão de normalidade da audiometria de tronco encefálico (BAEP) nas diversas faixas etárias. Rev. Bras. Otorrinolaringol., v.54, p.3741, 2009.

BODENHAMER, R.D.; HUNTER, J.F.; LUTTGEN, P.J. Brain stem auditory evoked response in the dog. Am. J. Vet. Res., v.46, p.1787-1792, 1985.

CHIAPPA, K.H. Brain stem auditory evoked potentials: methodology. In: CHIAPPA, K.H. (ed.) Evoked Potentials in Clinical Medicine. 3.ed. Philadelphia, Pennsylvania: Lippincott-Raven, 1997. p.157-197.

HAAGEN, V.A.J.; SIEMELINK, R.J.G.; SMOORENBURG, G.F. Auditory brainstem response in the normal beagle. Vet. Quart., v.11, p.129-137, 1989. 
HAAR, G.T.; VENKER-VAN HAAGEN, A.J.; VAN DEN BROM, W.E. et al. Effects of aging on brainstem responses to toneburst auditory stimuli: a cross-sectional and longitudinal study in dogs. J. Vet. Intern. Med., v.22, p.937-945, 2008.

HARCOURT-BROWN, T.R.; PARKER, J.E.; GRANGER, N. et al. Effect of middle ear effusion on the brain- stem auditory evoked response of Cavalier King Charles Spaniels. Vet. J., v.188, p.341-345, 2010 .

HOLLIDAY, T.A.; TE SELLE, M.E. Brain stem auditory-evoked potentials of dogs: wave forms and effects of recording electrode positions. Am. J. Vet. Res., v.46, p.845-851, 1985.

KAWASAKI, Y.; INADA, S. Peaks of brainstem auditory evoked potentials in dogs. Vet. Res. Commun., v.18, p.383-396, 1994.

KAY, R.; PALMER, A.C.; TAYLOR, P.M. Hearing in the dog as assessed by auditory brainstem evoked potentials. Vet. Rec., v.114, p.81-84, 1984.

KNOWLES, K.E.; CASH, W.C.; BLAUCH, B.S Auditory-evoked responses of dogs with different hearing abilities. Can. J. Vet. Res., v.52, p.394-397, 1988.

LUTTGEN, P.J. Deafness in the dog and cat. Vet. Clin. North Am., v.24, p.981-989, 1994.

MARSHALL, A.E. Brain stem auditory-evoked response of the nonanesthetized dog. Am. J. Vet. Res., v.46, p.966-973, 1985.

MARSHALL, A.E. Use of brain stem auditory-evoked response to evaluate deafness in a Dalmatian dogs. $J$. Am. Vet. Med. Assoc., v.188, p.718-722, 1986.

MEIJ, B.P.; VENKER-VAN HAAGEN, A.J.; VAN DEN BROM, W.E. Relationship between latency of brainstem auditory-evoked potentials and head size in dogs. Vet. Quart., v.14, p.121-126, 1992.

MUHLE, A.C.; JAGGY, A.; STRICKER, C. et al. Further contributions to the genetic aspect of congenital sensorineural deafness in Dalmatians. Vet. J., v.163, p.311-318, 2002.

PLATT, S.; FREEMAN, J.; STEFANI, A.D. et al. Prevalence of unilateral and bilateral deafness in Border Collies and association with phenotype. J. Vet. Intern. Med., v.20, p.1355-62, 2006.
POOK, H.A.; STEISS, J.E. Correlation of brain stem auditory-evoked responses with cranium size and body weight of dogs. Am. J. Vet. Res., v.51, p.1779-1783, 1990

STEISS, J.E.; COX, N.R.; HATHCOCK, J.T. Brain stem auditory-evoked response abnormalities in 14 dogs with confirmed central nervous system lesions. $J$. Vet. Intern. Med., v.8, p.293-298, 1994.

STRAIN, G.M. Hereditary deafness. In: Deafness in dogs and cats. OxfordShire: Cabi, 2011. p.53-69.

STRAIN, G.M. Aetiology, prevalence and diagnosis of deafness in dogs and cats. Br. Vet. J., v.152, p.1736, 1996.

STRAIN, G.M. Congenital deafness and its recognition. Vet. Clin. North Am. Small Anim. Pract., v.29, p.895-907, 1999.

STRAIN, G.M. Deafness prevalence and pigmentation and gender associations in dog breeds at risk. Vet. J., v.167, p.23-32, 2004

STRAIN, G.M.; KEARNEY, M.T.; GIGNAC, I.J. et al. Brainstem auditory-evoked potential assessment of congenital deafness in Dalmatians: associations with phenotypic markers. J. Vet. Intern. Med., v.6, p.175182,1992

TRUNE, D.R.; MITCHELL, C.; PHILLIPS, D.S. The relative importance of head size, gender and age on the auditory brainstem response. Hea. Resea.. v.32, p.165-74, 1988.

UZUKA, W.; FURUTA, T.; YAMOAKA, M. et al. Threshold changes in auditory brainstem response (ABR) due to the administration of kanamycin in dogs. Exp. Anim., v.45, p.325-331, 1996.

WEBB, A.A. Brainstem auditory evoked response (BAER) testing in animals. Can. Vet. J., v.50, p.313$318,2009$.

WILSON, W.J.; MILLS, P.C. Brainstem auditoryevoked response in dogs. Am. J. Vet. Res., v.66, p.2177-2187, 2005.

WOOD, J.L.N.; LAKHANI, K.H. Deafness in Dalmatians: does sex matter? Prev. Vet. Med., v.36, p.39-50, 1998 . 